Journal of Teacher Education for Sustainability, vol. 16, no. 2, pp. 103-114, 2014

\title{
The Journey towards a Teacher's Ecological Self: A Case Study of a Student Teacher
}

\author{
Rea Raus \\ Tallinn University, Estonia \\ Thomas Falkenberg \\ University of Manitoba, Canada
}

\begin{abstract}
Transforming our educational systems to support sustainable development is a challenge that involves all levels of education - policy, curriculum and pedagogical practice. One critical dimension to look at is a teacher's identity as it influences a teacher's decisionmaking, behaviour and action. The ecological self is the concept that is used in the context of sustainability. This paper discusses the emerging ecological self of one student teacher during her initial teacher education programme. The concepts of the teacher's self and the ecological self form a lens through which the story of this student teacher is examined. The paper focuses on one part of a broader, longitudinal study of student teachers and their understanding of pedagogy and connectedness with nature in the context of the need for reorienting teacher education towards sustainability. Sterling's (2001) conceptual framework of ecological view on education is taken as a tool to analyse the collected data. The results indicate that deep connectedness to nature and empathy are framing the holistic view on learning, teaching and a teacher's self.
\end{abstract}

Keywords: teacher education, student teacher's identity, ecological self, sustainability, worldviews

The idea of sustainable development as a concern for creating and sustaining the conditions for current and future generations to live well on the Earth was introduced by Brown (1981) and was adopted by the United Nation's World Commission on Environment and Development (WCED, 1987), "Sustainable development is development that meets the needs of the present without compromising the ability of future generations to meet their own needs" (p. 43). According to Ospina (2000), sustainability is primarily a "moral precept" (p. 32), because the problem of "sustainability is not a problem of and for the Earth, but a human values problem" (Babiuk \& Falkenberg, 2010, p. 9). Accordingly, sustainable development requires changes in values and attitudes towards the environment (WCED, 1987). Education - a particular formal education - has to play a central role in achieving those changes in values and attitudes. Recognising that 
teacher education through its mandate of preparing teachers for their educational work plays an important support role for this educational undertaking, the United Nations Educational, Scientific and Cultural Organization (UNESCO) initiated in 1998 and has been supporting effort for reorienting teacher education towards sustainability, which was followed by the formation of an international network of teacher education institutions (McKeown \& Hopkins, 2007). The literature on reorienting teacher education towards sustainability around the world highlights promising exemplars, but it also paints a picture of very slow progress (Sims \& Falkenberg, 2014). With a number of important institutional challenges to such a reorientation towards sustainability (Hopkins \& McKeown, 2005), there is also the fundamental challenge for teacher education. This paper engages with this latter challenge through a case study of one student teacher and the development of her "ecological self". The next section will outline the theoretical framework for the case study, which will involve the notions of the self of a teacher more generally and a teacher's ecological self, more specifically.

\section{Theoretical Framework}

The theoretical framework that underlies the case study reported upon in this paper has two components: the first one deals with the notion of a teacher's self and its role in teacher education, but the second one concerns what has been called a person's "ecological self" (Naess, 1987/1995), a notion we want to expand to a "teacher's ecological self". We shall outline the two components of the framework in turn.

\section{A Teacher's Self and Its Role in Teaching and Teacher Education}

A teacher's identity and self have been identified as important constructs in teacher education (Beijaard, Meijer, \& Verloop, 2004; Nias, 1993; Olsen, 2008). One particular approach to a teacher's self that fits this perspective and that we like to draw upon as part of our study's theoretical framework is Korthagen's $(2004,2013)$ "onion model," which he conceptualises as "a model of levels of change" (Korthagen, 2004, p. 80), which we look at as a model of the different layers that make up a teacher's self. There are five such layers that are ordered from "outside" to "inside", hence, the "onion" model: a teacher's behaviour; a teacher's competencies; a teacher's beliefs; a teacher's identity and a teacher's mission. Thus, a teacher's self is characterised by his/her behaviour, competencies, beliefs, identity and mission. The image of the layers of an onion make two central features of a teacher's self clear, features that we adopt as part of our theoretical framework: that all layers are "touching" each other, either directly or indirectly; and that it is more difficult to get at the inner layers than the outer layers. A teacher's "behaviour, his or her being is grounded in an awareness of self, mission and core qualities” (Korthagen, Hoekstra, \& Meijer, 2014, p. 80). There is a certain alignment between the layers: for instance, one's mission as a teacher should be aligned or in harmony with one's beliefs about teaching and learning, and those beliefs should be aligned with one's behaviour. The problems here is that the "self concepts are quite resistant to change" (Korthagen, 2004, p. 83).

It is obvious what important role a teacher's self, as conceptualised in such a way, plays for a teaching practice and also for professional development of a teacher. In order to align the "layers" of a teacher's self, a teacher's behaviours, competency develop- 
ment and beliefs need to be aligned with his/her mission and identity as a teacher and a person. This means that teaching cannot be seen as being solely a matter of a teacher's behaviour and competency, but also as a matter of his/her beliefs, identity and mission. This also makes clear the important role a student teacher's self plays for the design and practice of a teacher education programme that wants to impact a student teacher's teaching practice: the programme cannot only focus on the student teacher's teaching behaviour and his/her teaching competencies, but must also give consideration to his/ her beliefs, identity and even mission (in life and teaching).

\section{The Ecological Self and Its Role in Teaching and Teacher Education}

Hedlund-de Witt (2013a, b) suggests that an understanding of worldviews - which we can understand as a construct made up of the three inner layers of a person's self: a mission, an identity and beliefs - has a major role in addressing our highly complex, multifaceted, interwoven, planetary sustainability issues. She draws attention to the understanding of several authors (Hulme, 2009; Vonk, 2011) that worldviews are a "root-cause" of our sustainability challenges. Worldviews are clearly important in searching for solutions to the problems our societies are facing.

This perspective gives rise to the notion of "ecological self", which is at the core of the deep ecology movement (Dregenson \& Inoue, 1995), which started with Naess (1973). The ecological self is a deepened and widened self whose identity (the second inner layer) is one that identifies with one's natural ecology into which one is embedded so that any destruction of that natural ecology is a destruction of one's self (Naess, 1987/1995).

The role of the ecological self in teaching and teacher education becomes clear when one draws on Sterling's (2001) dichotomy between a mechanistic (instrumental) and a holistic (ecological) view of the world, which, in turn, leads to a dichotomy in the view of teaching and learning between a mechanistic (instrumental) and a holistic (ecological) view of educational values (Table 1) and teaching and learning (Table 2).

Table 1

Mechanistic and Ecological/Holistic Educational Paradigms (Sterling, 2001)

\begin{tabular}{ll}
\hline \multicolumn{1}{c}{ Mechanistic View } & \multicolumn{1}{c}{ Ecological/Holistic View } \\
\hline Preparation for economic life & $\begin{array}{l}\text { Participation in all dimensions of the sustainability tran- } \\
\text { sition-social, economic, environmental }\end{array}$ \\
\hline Selection or exclusion & Inclusion and valuing of all people \\
\hline Formal education & Learning throughout life \\
\hline Knowing as instrumental value & Being/becoming (intrinsic/instrumental values) \\
\hline Competition & Co-operation, collaboration \\
\hline Socialization, integrating to fit & Autonomy-in-relation \\
\hline Effective learning & Transformative learning \\
\hline Standardisation & Diversity with coherence \\
\hline Accountability & Responsibility \\
\hline Specialisation & Integrative understanding \\
\hline Faith in “the system" & Faith in people \\
\hline Modernity & Ecological sustainability \\
\hline
\end{tabular}


Table 2

Mechanistic and Ecological/Holistic Views of Teaching and Learning (Sterling, 2001)

\begin{tabular}{ll}
\hline \multicolumn{1}{c}{ Mechanistic View } & Transformation \\
\hline Transmission & Process, development, action oriented \\
\hline Product oriented & $\begin{array}{l}\text { Integrative view: teachers also learners, learners also } \\
\text { teachers }\end{array}$ \\
\hline Emphasis on teaching & Functional, critical and creative competencies valued \\
\hline Functional competence & As a whole person with full range of needs and capacities \\
\hline View of learner & Existing knowledge, beliefs and feelings valued \\
\hline As a cognitive being & Differentiated needs recognised \\
\hline Deficiency model & Intellect, intuition and capability valued \\
\hline Learners largely undifferentiated & Multiple intelligences \\
\hline Valuing intellect & Teachers as reflective practitioners and change agents \\
\hline Logical and linguistic intelligence & Groups, organisations and communities also learn \\
\hline Teachers as technicians &
\end{tabular}

Table 1 and Table 2 illustrate how different the teaching behaviours and competencies, i.e. outer layers of a teacher's self, match the mechanistic inner self from those that match the ecological, holistic inner self. The ecological self that addresses relevant worldview requires quite different competencies and behaviours from teachers, and, thus, also different approaches to teacher education.

The study that we report upon in this paper is a case study of the emerging ecological self of one particular student teacher enrolled in a particular master's degree teacher education programme. The theoretical framework - the notion of a teacher's self and the notion of the ecological self - was used as the framework for designing the case study and as a lens through which the data were analysed.

\section{Methodology}

The case study reported upon in this paper is part of a broader, longitudinal study investigating the student teachers' emerging ecological self while enrolled in a teacher education programme. We consider the case we report upon in this paper a critical case (Yin, 2009), which allows us to better understand what the emerging ecological self in student teachers could look like. Such an understanding would be of great benefit to the educational endeavour of reorienting teacher education towards sustainability.

The female student teacher presented in this case study, whom we gave the pseudonym Marygold for the purpose of the study, attended a teacher education programme at a Baltic university at the time the data for the study were collected. Marygold, as one of the participants of the broader study, was selected to take part in the study. The aim of the broader study was to investigate what personal and professional identities/selves student teachers bring into teacher education by looking at students' views towards teaching, learning and nature.

The data for the broader study consisted of written responses to open-ended questions and semi-structured group and individual interview data. The broader, longitudinal study, from which the data for the case study were drawn, involved nine student teachers 
and collected data during a four-year-period, starting at the beginning of their studies and ending with the final year of their studies, leaving out the final year of the master's thesis work. After an initial analysis of the data, during the third year of studies, Marygold stood out as a critical case for the study of the emerging ecological self in student teachers, so much so that we decided to report on her case separately in this paper as a critical case study. The data for this case study were drawn from that part of the broader study that investigated the student teachers' worldviews and attitudes related to pedagogy and nature. For this part of the study, the written open-ended questions (OEQ) included questions about the understanding of learning and teaching, description of a favorite or ideal teacher, personal memories of school, motivation and mission to become a teacher. The questions of the semi-structured interviews (INT) aimed at a deeper discussion of the student teachers' understanding of learning and teaching, their views of the qualities and competencies of good teachers and what they would consider their mission in becoming a teacher is.

For the data analysis, first, the written text responses to open-ended questions and the transcribed interview data were read several times to find emerging themes. Inductive content analysis was used in order to categorise themes emerging from the text data, which then were reduced to the main categories (Mayring, 2000). Using the theoretical framework outlined above, categories concerning attitudes towards nature and pedagogy were unified as aspects of a central category to be investigated.

\section{Findings and Discussion}

The findings section is divided into two parts, reflecting the two aspects of our theoretical framework. The first section will describe and discuss the findings linked to Marygold's teacher self with a focus on the three inner layers of a teacher's self: a mission, an identity and beliefs. The second section will describe and discuss the findings linked to Marygold's ecological self.

\section{A Teacher's Self: A Mission, an Identity and Beliefs}

Marygold comes from a family of teachers ("I was really proud of them", she says.), so her background has given a certain level of understanding of a teacher's work. A mission of her life - what inspires her as a future teacher - is to be as good a teacher as her favourite teacher, who makes students think, develops their worldviews and guides their development. The quotation also suggests a number of beliefs that Marygold holds about teaching: teaching is about making students think, developing their worldviews and guiding their development; being a teacher is like being a parent of one's students. Beliefs and mission seem to be well-aligned, as Korthagen (2013) has suggested is the case for those teachers who "teach from within".

When I was little, I thought that teaching was a very appreciated job, with a mission, because some of my mother's students were practically like the members of our family... My favourite teacher could make us think, contemplate on things, she managed to develop our worldviews... (for me) teaching is guiding, being an example, supporting children's development. I would like to be as my favourite teacher was. The aim of that is to see good sides and 
potential in every student and helping them to develop this potential better... A teacher is still like another mother for a child, not directly, but still indirectly... She should be a well-educated person... I mean know her subject, but knowing also about greater, worldly matters... I am actually really eager to see how I manage with that. (Marygold, OEQ)

Marygold's experience of her mother's students being like family members seems to have shaped her belief that teachers should be like the parents of her students. Nias's (1989) remark on Peztalozzi, who suggested that a teacher should live and work among his/her pupils, seems to have been a reality in Marygold's mother's case.

Marygold refers to her being abroad for a longer period, opening her eyes to what teaching and learning should really be, comparing the experience to what she had at school.

When I was in primary school and in secondary school, I thought that this is how things should be [teachers teach and students learnby heart], but after that ... my eyes opened. I saw that teaching can be approached differently. ... well... I am very demanding, and I never actually accuse anyone, but... I think that a teacher should be always an example for students. And a student should be striving to be exemplary... This makes teaching so much easier for a teacher and, actually, for a student as well. I have had such teachers. (Marygold, INT)

This quotation illustrates well how certain kinds of life experiences - in Marygold's case, experiences of teaching and learning abroad - can shape a student teacher's beliefs about teaching and, as in Marygold's case, her mission in life (to become a teacher who is like her favourite teacher). Marygold is striving to be an example to her students. Being demanding, as she says, shows that she is not ready to compromise on important matters like learning; this also is part of her identity as a teacher, who she is in her work as a teacher.

The few quotations illustrate our understanding of Marygold's teacher self - her mission, identity and beliefs about teaching and being a teacher. The next section will use the data from Marygold to illustrate an emergent ecological self as outlined in the theoretical framework.

\section{A Teacher's Ecological Self}

The following tables use data collected from Marygold to illustrate how Marygold's self fits well with the ecological/holistic educational paradigm identified by Sterling (2001) and referenced above (Table 1) as well as with Sterling's (2001) ecological view of teaching and learning (Table 2). Accordingly, Marygold's understanding is differentiated into the categories (Table 3 ). 
Table 3

Marygold: Ecological/Holistic Educational Paradigm

Ecological/Holistic Values

Inclusion and valuing of all people

The aim of that is to see good sides and potential in every student and helping to develop this potential better. (Marygold, OEQ)

Being/becoming (intrinsic/instrumental values)

I think educating means helping the student to find his/her path. (Marygold, OEQ)

Co-operation, collaboration

It (learning) could be like everything is... like worked through together (by a teacher and students). (Marygold, OEQ)

Autonomy-in-relation

... it was not like that you got some real insights, a greater understanding... I didn't like it. Maybe others want to study like that, but I don't. Referring to her decision about career choice. (Marygold, INT)

Integrative understanding

I mean knowing her subject, but knowing also greater, worldly matters. (Marygold, INT)

Faith in people

When I wake up in the morning and think that all people are good and the sun is shining and today is a wonderful morning... and I just go and take a walk. This worldview seems naive and too young, but this is how I can manage with life. This thought actually scares me nowif I would think ill thoughts about people. I'll try to see good in everyone; if there is a badbehaving child, then there is a reason for that. No person is born bad. They grow to be like that. This is what I think. (Marygold, INT)

Table 4 gives a summary of Marygold's holistic understanding of what teaching and learning is or should be.

Table 4

Marygold: Ecological/Holistic View of Teaching and Learning

Ecological View on Learning and Pedagogy

Transformation

I think educating means helping the student to find his path. ... what you are good at and how to (benefit) from it in the future. (Marygold, OEQ)

As a whole person with full range of needs and capacities

The aim of that is to see good sides and potential in every student and helping to develop this potential better. (Marygold, OEQ)

Differentiated needs are recognised.

For example, if a student likes to read, helshe can get knowledge and background information, which is very important to ground the knowledge, by reading. Or when some other student likes to put everything down in writing ... so ... how and in what way ... all this. (Marygold, OEQ).

Teachers as reflective practitioners and change agents

My favourite teacher could make us think, contemplate on things, she managed to develop our worldviews (for me) teaching is guiding, being an example, supporting a child's development. (Marygold, OEQ)

Groups, organisations and communities also learn, and teachers are learners too. (Learning) could be like everything is... like working through together. New alternatives are seen, problems are solved, not created instead. (Marygold, OEQ) 
In exploring further Marygold's ecological self, we focus on one particular aspect of her ecological self, namely her relationship with nature, which is central to Naess's (1987/1995) understanding of the ecological self. Marygold's relationship with nature as an integral component of her ecological self emerges in her stories when she discusses everyday life and her attitude towards nature. Knowledge about nature comes from her childhood, as her mother introduced her to different species during long walks in natural environment. Marygold confesses that she is actually afraid of being in nature alone, explaining that she is not used to it and that she has not had the chance to be alone in nature so much. At the same time, she longs for a deeper experience and wants to spend more time in nature, practicing this connectedness. Despite being afraid, she is aware of the reasons for it, and she sees the value of connectedness, understands the need for developing it.

Someday, I would like to live in connection with nature. I think the more we consume, the worse and I am really in favour of everything [that protects nature]... but I think that we have not yet come to the situation where people and nature can unite. We just don't have... the world has to change for that. I believe that these changes will occur; just a lot of time has to pass, maybe 200 or 300 years. I don't believe my eyes will actually see an ideal world. (Marygold, INT)

Marygold sees the separation from nature as being something unnatural and considers modern lifestyles a cause for this separation, but she also hopes that the situation will change. The ideal world for her is when people feel connected with nature. This reflects the core idea of Naess's (1987/1995) notion of the ecological self, which is even more explicitly expressed in the following description.

I think that a human being and nature have been separated so much now, that humans begin to change into something else. We shall evolve and develop into something different than we would be if we lived in harmony with nature. Well, you can see it, really, sure. Even our reflexes change and everything. People cannot see things in depth, they cannot concentrate, just to be there... I myself, I am not perfect at all. I think, today, being eco-friendly is a fulltime job, to be with nature in our times. There is a long way to go... but I totally enjoy and value those moments when I can leave my phone or there is no connection - this is a wonderful and comfortable reality then. (Marygold, INT)

Looking at the separation of people from nature, she sees it as an unnatural process that changes the very core of being a human. Despite worrying that she is not able to see how the connection can be restored, she sees hopeful tendencies. When it comes to other people, Marygold prefers to search for good qualities in them. There is always a reason, a set of environmental factors that negatively influence people's actions and behaviors.

When I wake up in the morning, I think that all people are good and the sun is shining and today is a wonderful morning... and I just go and take a walk. This worldview seems naive and too young, but this is how I can manage with life. This thought actually scares me now - if I would think bad thoughts 
about people. I'll try to see good in everyone; if there is a bad-behaving child, then there is a reason for that. No person is born bad. They grow to be like that. This is what I think. (Marygold, INT)

In the next quotation she talks about the inner beliefs of her ecological self; she sees that the "Greater Being" is in every one of us, which is a view often found in the deep ecology movement (Berry, 1988), as well as in the literature on the role of spirituality in education (Miller, 2000). While not always explicitly linked to the literature on spirituality, Marygold's view is connected with whole systems thinking that is influencing stewardship (Senge, 1990; Senge, Smith, Kruschwitz, Laur, \& Schley, 2008).

I believe in myself. I believe there is something greater inside me. When some people pray to God, I ask for those things for myself. I ask to be better, I ask for more dignity, to be more pretty... whatever. This is with everything, it is so special really, that we talk, communicate, are alive. This is so much bigger than that. And it all is in us. It is also, in the same way, special, as we wake up in the morning and use this incredible day, what has been given to us, what we are supposed to be happy about. Either we talk about the neighbour all day (referring to meaningless chat about other people), or we do what we really like to do (referring to meaningful actions one should do). In a real way... (Marygold, INT)

The feeling of oneness she expresses here, that all people share something that is the same, reflects the altruistic self very well. Naess (1987/1995) speaks about it as a core aspect of the ecological self. The importance of an individual's effort for the greater good is linked to the point that Makrakis and Kousoulas-Makrakis (2012) made about teaching and creating a teacher education curricula. They stress that we should bear in mind that the learners have to be able to transform themselves and society, which makes it especially important to address the notion of self in the context of teacher education for sustainability. Also, Marygold seems to understand that everything we do or say may have a far broader influence on the world; again a view inherent in the scholarship of whole systems.

\section{Conclusion}

As it has been stated, reorienting teacher education towards sustainability has been recognised as an important approach to address the urgent need for sustainable development, i.e., creating and sustaining the conditions for current and future generations to live well on the Earth. The work by deep ecologists like Naess (1973) provides an understanding of the importance of our selves (particularly our mission in life, our identity and our beliefs) for creating and sustaining those conditions. Thus, the concern for developing our ecological selves, as conceptualised by deep ecologists like Naess, 1987/ 1995 , needs to become an important focus for reorienting teacher education for sustainability. While Sterling (2001) provides a conceptual framework for a greater understanding teachers' ecological selves, the question about what those ecological selves actually look like in teachers, why and how they emerge remain unanswered. When analysing data for the broader study mentioned above, Marygold's responses stood out as what we would consider a critical case for a deeper understanding what a developing ecological 
self in student teachers might look like. Our analysis and discussion on her response data from the broader study, we hope, provides a helpful case study of a developing teacher's ecological self for the purpose of addressing issues related to the development of teacher education towards sustainability. We think that this case study can do so in two important ways. First, the core layers of a student teacher's ecological self-mission, identity and beliefs, as identified in the core refection approach to teacher education (Korthagen, 2013), have been illustrated through the personal story of a particular student teacher. This illustration, through a concrete case, can help sensitise teachers' educators to the qualities that characterise an ecological self in terms of one's mission, identity and beliefs. It seems to us that being sensitised as a teachers' educator to those qualities is a prerequisite for working with student teachers with the goal of reorienting teacher education towards sustainability. Murray (2011) has made a strong argument for the importance of "the sustainable self" for education for sustainable development. In his book "Sustainable Self", he provides pedagogical models and concrete methods to approach the construction of sustainable self during the learning process.

Our case study can also support the design of further studies on evolving student teachers' identities. Of course, one case study does not provide enough evidence to make profound conclusions or suggestions, but it enables readers to consider different aspects when we discuss more diverse studies in the field. A second way in which we think our critical case study can support reorienting teacher education towards sustainability is by providing a concrete illustration of the theoretical framework provided by deep ecologists for reorienting teacher education for sustainability. Marygold's responses illustrate what Naess's (1987/1995) notion of the ecological self can look like in the context of teaching, and they illustrate what Sterling's (2001) ecological/holistic educational paradigm and ecological view on learning and pedagogy mean. We suggest that these theoretical frameworks are of great importance to a systematic approach to reorienting teacher education towards sustainability, thus having an illustrative example for those theoretical constructs could be helpful - also for future studies on evolving student teachers' identities.

Reorienting teacher education towards sustainability means that teacher education programmes need to work "from within" (Korthagen, Kim, \& Greene, 2013) with student teachers' selves, and a clear understanding of what ecological selves "look like" can represent an important aspect of such work from within.

\section{Acknowledgement}

The authors gratefully acknowledge support from the European Social Fund (grants no. 1.2.0401.09-0070).

\section{References}

Babiuk, G., \& Falkenberg, T. (2010). Sustainable development and living through changing teacher education and teaching in Manitoba. Retrieved from http://home. cc.umanitoba.ca/ falkenbe/Publications/Publications.html

Beijaard, D, Meijer, P. C., \& Verloop, N. (2004). Reconsidering research on teachers' professional identity. Teaching and Teacher Education, 20, 107-128.

Berry, T. (1988). The dream of the earth. San Francisco: Sierra Club Books. 
Brown, L. B. (1981). Building a sustainable society. New York: Norton.

Dregenson, A., \& Inoue, Y. (1995). (Eds.). The deep ecology movement: An introductory anthology. Berkeley, CA: North Atlantic Books.

Hedlund-de Witt, A. (2013a). Pathways to environmental responsibility: A qualitative exploration of the spiritual dimension of nature experience. Journal for the Study of Religion, Nature, and Culture, 7(2), 154-186.

Hedlund-de Witt, A. (2013b). Worldviews and the transformation to sustainable societies: An exploration of the cultural and psychological dimensions of our global environmental challenges (Unpublished doctoral dissertation). Vrieje University, Amsterdam, the Netherlands.

Hopkins, C. A., \& McKeown, R. (2005). Guidelines and recommendations for reorienting teacher education to address sustainability. Retrieved from http://unesdoc. unesco.org/images/0014/001433/143370e.pdf

Korthagen, F. A. J. (2004). In search of the essence of a good teacher: Towards a more holistic approach in teacher education. Teaching and Teacher Education, 20, 7797. doi:10.1016/j.tate.2003.10.002

Korthagen, F. A., J. (2013). The core reflection approach. In F. A. J. Korthagen, Y. M. Kim \& W. L. Greene (Eds.), Teaching and learning from within: A core reflection approach to quality and inspiration in education (pp. 24-41). New York: Routledge.

Korthagen, F. A. J., Hoekstra, A., \& Meijer P. C. (2014). Promoting presence in professional practice: A core reflection approach for moving through the U. In O. Gunnlaugson, C. Baron \& M. Cayer (Eds.), Perspectives of the theory U: Insight from the field (pp. 77-96). Business Science Reference.

Korthagen, F. A. J., Kim, Y. M., \& Greene, W. L. (2013). (Eds.). Teaching and learning from within: A core reflection approach to quality and inspiration in education. New York: Routledge.

Makrakis, V., \& Kostoulas-Makrakis, N. (2012). Course curricular design and development of the M. Sc. programme in the field of ICT in education for sustainable development. Journal of Teacher Education for Sustainability, 14(2), 5-40.

Mayring, P. (2000). Qualitative content analysis. Retrieved from http://www.qualitativeresearch.net/index.php/fqs/article/view/1089/2385

McKeown, R., \& Hopkins, C. (2007). International network of teacher education institutions: Past, present and future. Journal of Education for Teaching, 33(2), 149-155. doi:10.1080/02607470701259408

Miller, J. P. (2000). Education and the soul: Toward a spiritual curriculum. Albany, NY: State University of New York Press.

Murray, P. (2011). The sustainable self: A personal approach to sustainability education. London: Earthscan.

Naess, A. (1973). The shallow and the deep, long-range ecology movement: A summary. Inquiry, 16, 95-100.

Naess, A. (1987/1995). Self-realization: An ecological approach to being in the world. In A. Drengson \& Y. Inoue (Eds.), The deep ecology movement: An introductory anthology (pp. 13-30). Berkeley, CA: North Atlantic Books.

Nias, J. (1989). Primary teachers talking: A study of teaching as work. London: Routledge. 
Nias, J. (1993). Changing times, changing identities: Grieving for a lost self. In R. G. Burgess (Ed.), Educational research and evaluation: For policy and practice? (pp. 139156). London: Routledge.

Olsen, B. (2008). Introducing teacher identity and this volume. Retrieved from http://www.teqjournal.org/backvols/2008/35_3/05introduction.pdf

Ospina, G. L. (2000). Education for sustainable development: A local and international challange. Retrieved from http://collections.infocollections.org/ukedu/en/d/Jh1935e/ 2.1.html\#Jh1935e.2.1

Senge, P. M. (1990). The fifth discipline: The art and practice of learning organizations. New York: Currency Doubleday.

Senge, P., Smith, B., Kruschwitz, N., Laur, J., \& Schley, S. (2008). The necessary revolution: How individuals and organizations are working together to create a sustainable world. New York: Doubleday.

Sims, L., \& Falkenberg, T. (2013). Developing competencies for education for sustainable development: A case study of Canadian faculties of education. International Journal of Higher Education, 2(4), 1-14. doi:10.5430/ijhe.v2n4p1

Sterling, S. (2001). Sustainable education: Re-visioning learning and change. Totnes, Devon, UK: Green Books.

World Commission on Environment and Development (WCED). (1987). Our common future. New York: Oxford University Press.

Yin, R. K. (2009). Case study research: Design and methods (4 ${ }^{\text {th }}$ ed.). Lost Angeles, CA: Sage.

Correspondence concerning this paper should be addressed to Rea Raus, a PhD candidate, Institute of Educational Sciences, Tallinn University, Uus-Sadama 5, 10120, Estonia.Email: rearaus@tlu.ee 